\title{
PROFIL FAKTOR KEPRIBADIAN MALADAPTIF PADA DEWASA AWAL: STUDI DESKRIPTIF
}

\author{
Ray Caesarly Santosa ${ }^{1}$, Rismiyati E. Koesma ${ }^{2}$, dan Zamralita ${ }^{3}$ \\ ${ }^{1}$ Program Studi Magister Psikologi Profesi, Universitas Tarumanagara Jakarta \\ Email: ray.717181017@stu.untar.ac.id \\ ${ }^{2}$ Fakultas Psikologi, Universitas Tarumanagara Jakarta \\ Email: tettyris23@gmail.com \\ ${ }^{3}$ Fakultas Psikologi, Universitas Tarumanagara Jakarta \\ Email: zamralita@fpsi.untar.ac.id
}

Masuk : 12-10-2020, revisi: 25-10-2020, diterima untuk diterbitkan : 31-10-2020

\begin{abstract}
Personality disorder is an incapacitating mental illness that leads the individual to some negative consequences, often deadly. However, to date, no studies have been conducted to determine the prevalence of personality disorders in Indonesia. This could happen due to the fact that personality disorders often co-morbid with other mental disorders making them difficult to detect. According to Alternative Model for Personality Disorders (AMPD), personality disorders can be diagnosed by the presence of maladaptive personality factors in oneself. There are five maladaptive personality factors according to the model: Negative Affectivity, Detachment, Disinhibition, Antagonism, and Psychoticism. Therefore, this study aims to get an overview of the maladaptive personality factors and describe the maladaptive personality characteristics in order to detect the symptoms of personality disorders in community sample. Through survey and descriptive analysis of 608 emerging adults $(M$ age $=19.66$ y.o, SD = 1.895), the study found that $1.2 \%$ are classified in High Personality Dysfunction category and $38.8 \%$ of the participants are classified in Low Personality Dysfunction category. The results showed that Negative Affectivity factor has the highest score for each group of the participants. In addition, the study also found the largest characteristic difference between groups of participants lies in the Psychoticism and Detachment factors. The study concludes by providing some avenues for further research and suggestions for mental health practitioners, and society in general.
\end{abstract}

Keywords: personality disorder, maladaptive personality trait, emerging adulthood, descriptive study

Gangguan kepribadian adalah gangguan mental serius dan dapat menyebabkan beberapa konsekuensi negatif pada penderitanya, termasuk kematian. Namun, hingga saat ini belum ditemukan studi mengenai prevalensi gangguan kepribadian di Indonesia. Hal tersebut dapat terjadi karena gangguan kepribadian seringkali bersanding dengan gangguan mental lain sehingga sulit terdeteksi. Menurut model alternatif untuk gangguan kepribadian (AMPD), gangguan kepribadian dapat dideteksi dengan keberadaan faktor kepribadian maladaptif dalam diri seseorang. Berdasarkan pendekatan AMPD, terdapat lima faktor kepribadian maladaptif, yaitu Negative Affectivity, Detachment, Disinhibiton, Antagonism, dan Psychoticism. Maka dari itu, penelitian ini bertujuan untuk mendapatkan gambaran atau profil kelima faktor kepribadian maladaptif guna memindai gejala gangguan kepribadian pada sampel dan gambaran karakteristik masyarakat secara umum. Melalui survei dan analisis deskriptif terhadap 608 orang dewasa awal $\left(\mathrm{M}_{\text {usia }}=19.66\right.$ tahun, $\left.\mathrm{SD}=1.895\right)$, ditemukan partisipan dengan tingkat disfungsi kepribadian tinggi sebesar $1.2 \%$ dan partisipan dengan tingkat disfungsi kepribadian rendah sebesar $38.8 \%$. Hasil juga menunjukkan bahwa faktor negative affectivity adalah faktor yang paling besar dimiliki oleh tiaptiap kelompok partisipan. Selain itu, perbedaan karakteristik paling besar antar kelompok partisipan terletak pada faktor psychoticism dan detachment. Studi disimpulkan dengan memberikan beberapa usulan untuk penelitian lebih lanjut, psikoterapis, dan masyarakat secara umum.

Kata Kunci: gangguan kepribadian, faktor kepribadian maladaptive, dewasa awal, studi deskriptif

\section{PENDAHULUAN}

\section{Latar Belakang}

Menurut APA (2013), gangguan kepribadian merupakan gangguan mental yang dicirikan dengan terganggunya fungsi diri dan interpersonal serta adanya sifat kepribadian patologis dalam diri seseorang yang relatif stabil dari waktu ke waktu dan termanifestasi pada berbagai situasi. Pada 
penelitian meta-analisis terhadap 113.998 individu dewasa, ditemukan bahwa angka prevalensi gangguan kepribadian pada populasi umum di negara Barat dapat dikatakan cukup tinggi, yaitu 12.16\% (Volkert, Gablonski, \& Rabung, 2018). Berkaitan dengan hal tersebut, di Indonesia, hingga saat ini belum ditemukan studi mengenai prevalensi gangguan kepribadian. Padahal, berdasarkan data Riset Kesehatan Dasar (RISKESDAS) teranyar (Kemenkes, 2013), prevalensi gangguan mental emosional di Indonesia sendiri adalah 6\%. Minimnya studi epidemiologis boleh jadi dapat disebabkan oleh masih minimnya pemahaman masyarakat Indonesia mengenai keberadaan, natur atau sifat, dan ragam gangguan mental seutuhnya, termasuk gangguan kepribadian (Anna, Februari 2012). Selain itu, kenyataan bahwa gangguan kepribadian seringkali bersanding dengan gangguan mental lain juga dapat menjadi salah satu faktor minimnya studi epidemiologis gangguan kepribadian (Lenzenweger, Lane, Loranger, \& Kessler, 2007).

Walaupun demikian, bukan berarti gangguan kepribadian dapat dipandang sebelah mata. Gangguan ini merupakan salah satu gangguan mental yang serius dan dapat berdampak negatif pada kehidupan individu yang mengalaminya (Volkert et al., 2018), seperti gangguan psikologis (Moran et al., 2016), penyakit fisik (Quirk et al., 2016), dan fungsi-fungsi sosial, seperti rasa kesepian (Liebke et al., 2017) serta konflik interpersonal (Wingenfeld et al., 2018). Adapun, gangguan kepribadian biasanya mengalami kemunculan pada masa remaja akhir atau dewasa awal (APA, 2013).

Pada Alternative Model for Personality Disorders (AMPD) yang tercantum dalam DSM-5 (APA, 2013), gangguan kepribadian didiagnosis berdasarkan keberadaan sifat kepribadian maladaptif dan tingkat keberfungsian kepribadian seseorang. Pendekatan tersebut sedikit berbeda dengan cara penegakkan diagnosis gangguan kepribadian yang ada pada Section II DSM-5 (APA, 2013). Walaupun demikian, penelitian-penelitian sebelumnya (Morey, Benson, \& Skodol, 2016; Fosatti et al., 2015; Bastiaens et al., 2015) membuktikan bahwa diagnosis gangguan kepribadian yang ditegakkan pada kedua pendekatan ini berkorelasi positif dan terbukti memiliki persamaan validitas konstruk.

Sifat kepribadian maladaptif yang tercantum mencakup 25 sifat yang tersusun ke dalam 5 domain (faktor) umum (Five Factor Model; FFM), yaitu Negative Affectivity, Detachment, Antagonism, Disinhibition, dan Psychoticism (APA, 2013). Negative Affectivity (NA) didefinisikan oleh APA (2013) sebagai kecenderungan yang dimiliki individu dalam merasakan pengalaman intensif dan frekuen akan berbagai perasaan negatif (seperti kecemasan, depresi, rasa bersalah/malu, khawatir, marah), dan bentuk manifestasi perilaku. Detachment (DT) didefinisikan oleh APA (2013) sebagai kecenderungan yang dimiliki individu untuk menghindari pengalaman sosioemosional, termasuk penarikan diri dari interaksi interpersonal (dari interaksi kasual sehari-hari hingga hubungan yang intim) dan ekspresi serta pengalaman afektif yang terbatas, terkhususnya pada kapasitas hedonis (kesenangan).

Antagonism (ANT) didefinisikan oleh APA (2013) sebagai kecenderungan yang dimiliki individu dalam berperilaku yang senantiasa menempatkan diri sebagai oposisi orang lain, termasuk di dalamnya adalah perasaan self-importance yang berlebihan yang beriringan dengan ekspektasinya untuk mendapatkan perlakuan spesial dari orang lain, serta adanya perasaan antipati terhadap orang lain, juga mencakup ketidaksadaran akan kebutuhan dan perasaan orang lain dan selalu berusaha memanfaatkan orang lain demi pemenuhan kebutuhan dan keinginan dirinya sendiri. Selanjutnya, Disinhibition adalah kecenderungan individu yang berorientasi pada gratifikasi yang segera sehingga mengakibatkan perilaku impulsif yang didasarkan pada pikiran, perasaan, dan stimulus yang sedang berlangsung, tanpa mempertimbangkan hasil belajar 
(learning) dan konsekuensi yang akan terjadi (APA, 2013). Tingkat disinhibition yang rendah dapat dicirikan dengan kurangnya faset rigid perfectionism. Terakhir, Psychoticism (PT) didefinisikan oleh APA (2013) sebagai kecenderungan yang dimiliki individu dalam menunjukkan ragam perilaku dan kognisi yang aneh, eksentrik, atau tidak wajar secara kultural, yang mencakup proses (contoh: persepsi, disosiasi) serta kontennya (contoh: kepercayaan).

Sama halnya dengan sifat, kelima faktor tersebut juga memiliki faktor risiko genetis yang sama dengan gangguan kepribadian pada Section II DSM-5 (Reichborn-Kjennerud et al., 2017). Konfigurasi dari kelima domain tersebut juga terbukti dapat memprediksi dan mendiferensiasi gangguan kepribadian yang muncul (APA, 2013). Dengan demikian, pengetahuan mengenai domain kepribadian maladaptif yang dimiliki seseorang menjadi penting untuk membantu praktisi psikologi klinis dalam melakukan asesmen terhadap gangguan kepribadian.

Adapun, berdasarkan hasil studi sebelumnya (Granieri et al., 2017), domain sifat kepribadian maladaptif yang paling banyak dimiliki oleh dewasa awal adalah Negative Affectivity. Akan tetapi, hingga saat ini, belum ditemukan studi deskriptif mengenai faktor kepribadian maladaptif di Indonesia. Oleh karena itu, tujuan utama dari penelitian ini bersifat eksploratif sehingga penelitian dilakukan dalam rangka menangkap fenomena secara empiris, dalam hal ini mendapatkan gambaran atau profil faktor kepribadian maladaptif yang dimiliki sampel penelitian agar dapat dimanfaatkan untuk mendeteksi sifat-sifat kepribadian maladaptif yang dapat berkembang menjadi gejala gangguan kepribadian dan mendapatkan gambaran mengenai faktorfaktor kepribadian maladaptif yang berkembang pada masyarakat secara umum. Hasil studi awal ini juga diharapkan dapat menjadi acuan untuk penelitian-penelitian sejenis pada kemudian hari.

\section{METODE PENELITIAN}

\section{Partisipan dan Prosedur Penelitian}

Partisipan penelitian ini berjumlah 608 individu dewasa awal dengan rentang usia 17-25 tahun. Berdasarkan gambaran data demografis partisipan, kebanyakan partisipan berjenis kelamin perempuan $(76.5 \%)$ dengan rata-rata usia 19.96 tahun $(\mathrm{SD}=1.895)$. Walaupun demikian, kebanyakan partisipan berusia 18 tahun (30.3\%). Partisipan yang berstatus sebagai mahasiswa/pelajar lebih banyak (89.1\%) jika dibandingkan pekerjaan lainnya, seperti wiraswasta, pegawai swasta, dan pegawai negeri sipil.

\section{Pengukuran faktor kepribadian maladaptif}

Definisi operasional tiap-tiap konstruk terukur dapat dilihat pada Tabel 1.

Tabel 1. Definisi operasional faktor kepribadian maladaptif

\begin{tabular}{ll}
\hline Konstruk & Definisi Operasional (Krueger et al., 2012; APA, 2013) \\
\hline Kepribadian Maladaptif & $\begin{array}{l}\text { Disfungsi pada kepribadian seseorang yang digambarkan dengan tingginya } \\
\text { afek negatif, perasaan keterpisahan, perilaku dan sikap antagonisme, } \\
\text { disinhibisi, dan psikotisme. }\end{array}$ \\
\hline Antagonism & $\begin{array}{l}\text { Kecenderungan yang dimiliki individu untuk senantiasa menempatkan diri } \\
\text { sebagai oposisi orang lain dan mementingkan diri sendiri. }\end{array}$ \\
\hline Detachment & $\begin{array}{l}\text { Kecenderungan yang dimiliki individu untuk menghindari pengalaman } \\
\text { sosioemosional. }\end{array}$ \\
\hline Nisinhibition & $\begin{array}{l}\text { Kecenderungan yang dimiliki individu untuk berorientasi pada gratifikasi } \\
\text { yang segera tanpa mempertimbangkan segala konsekuensi yang dapat } \\
\text { diterima. }\end{array}$ \\
\hline Kegative Affectivity & $\begin{array}{l}\text { Kenderungan yang dimiliki individu dalam mengalami pengalaman yang } \\
\text { intensif dan sering akan berbagai perasaan negatif yang berkadar tinggi. }\end{array}$ \\
\hline
\end{tabular}




\section{Instrumen Penelitian}

Alat ukur yang digunakan untuk mengukur domain kepribadian maladaptif adalah Personality Inventory for DSM-5 - Brief Form (PID-5-BF; Krueger et al., 2012) yang ditranslasi ke dalam Bahasa Indonesia. PID-5-BF merupakan versi singkat (brief) dari PID-5 (Krueger et al., 2011) yang berjumlah 25 butir self-report inventory yang digunakan untuk mengukur 5 domain kepribadian maladaptif pada Section III DSM-5. Kelima faktor kepribadian maladaptif yang terukur pada PID-5-BF, yaitu Negative Affectivity, Detachment, Antagonism, Disinhibition, dan Psychoticism. Tiap-tiap domain tersebut terukur melalui 5 butir positif. Butir-butir yang mengukur Negative Affectivity adalah butir 8, 9, 10, 11, dan 15. Contohnya adalah, "Saya mengkhawatirkan hampir segala hal." Selanjutnya, butir yang mengukur Detachment adalah butir 4, 13, 14, 16, dan 18. Contohnya adalah, "Saya jarang sekali merasa antusias pada setiap hal." Lalu, butir yang mengukur Antagonism adalah butir 17, 19, 20, 22, dan 25. Contohnya adalah, "Saya sangat mencari atau mendambakan perhatian." Selanjutnya, butir yang mengukur Disinhibition adalah butir 1, 2, 3, 5, dan 6. Contohnya adalah "Saya merasa perilaku saya cenderung impulsif." Terakhir, butir-butir yang mengukur Psychoticism adalah butir 7, 12, 21, 23, dan 24. Contohnya adalah, "Pikiran saya seringkali dianggap tidak masuk akal oleh orang lain."

Adapun, respon butir didasarkan pada 4 poin skala Likert yang berentang dari skor 0 (Sangat Tidak Tepat atau Seringkali Salah) hingga 3 (Sangat Tepat atau Seringkali Tepat). Dengan demikian, secara keseluruhan, skor terendah yang dapat dimiliki seseorang adalah 0 dan skor tertinggi yang dapat dimiliki seseorang adalah 75. Semakin tinggi skor yang dimiliki oleh seseorang berarti semakin tinggi juga disfungsi kepribadian yang dimilikinya secara umum (Krueger et al, 2012). Jika dilihat per faktornya, maka skor terendah yang dapat dimiliki seseorang pada satu faktor adalah 0 dan skor tertinggi yang dapat dimiliki seseorang adalah 15 . Skor yang semakin tinggi mengindikasikan tingkat disfungsi kepribadian yang semakin tinggi pada domain tersebut (Krueger et al, 2012).

Berdasarkan penelitian yang dilakukan oleh Anderson, Sellbom, dan Salekin (2018) terhadap tiga kelompok sampel, mahasiswa dan komunitas, nilai konsistensi internal Alpha Cronbach tiap-tiap faktor diketahui memadai agar dapat dikatakan reliabel. Pada kelompok sampel komunitas, nilai $\alpha$ memiliki rentang dari .70 (Negative Affectivity) hingga .75 (Disinhibition). Pada kelompok sampel mahasiswa 1, nilai $\alpha$ memiliki rentang dari .68 (Antagonism) hingga .78 (Disinhibition). Pada kelompok sampel mahasiswa 2, nilai a memiliki rentang dari .69 (Detachment) hingga .76 (Disinhibition). Anderson, Sellbom, dan Salekin (2018) juga menguji korelasi antara faktor PID-5-BF dan gangguan kepribadian pada PDQ-4 (Personality Diagnostic Questionnaire-4) dan PSY-5 (Personality Psychopathology-Five). Hasil yang didapatkan pun membuktikan bahwa trait-trait kepribadian maladaptif tersebut dapat memprediksi gangguan kepribadian yang sesuai secara teoritis secara signifikan.

Pada penelitiannya, Anderson, Sellbom, dan Salekin (2018) juga melakukan intraclass correlation yang membuktikan bahwa PID-5-BF memiliki daya ukur yang sama kuat dengan versi originalnya dan PID-5 Short Form (PID-5-SF), dengan nilai ICC yang berentang dari .87 99. Penelitian sebelumnya yang dilakukan oleh Bach, Maples-Keller, Bo, dan Simonsen (2016) juga membuktikan bahwa PID-5-BF memiliki daya ukur yang sama kuatnya dengan bentukbentuk PID-5 yang lainnya dan lebih sesuai jika digunakan untuk melakukan screening terhadap 
sampel klinis dan non-klinis dalam waktu yang terbatas. Berdasarkan Krueger et al. (2012), PID5-BF dapat digunakan untuk melakukan screening pada individu-individu sebelum dirujuk pada clinician.

Pada penelitian ini, dilakukan Second-Order Confirmatory Factor Analysis (CFA) untuk menguji validitas tiap-tiap butir yang mengukur kelima faktor dari konstruk Maladaptive Personality. Berdasarkan hasil CFA First-Order pada tiap-tiap domain kepribadian maladaptif, butir 2 harus dikeluarkan karena mengandung factor loadings yang negatif (Factor Loadings < 0.00) dalam mengukur faktor Disinhibition. Hal tersebut menandakan bahwa butir itu tidak valid dalam mengukur konstruk laten Disinhibition.

Melalui hasil CFA juga diketahui bahwa kelima indikator konstruk Kepribadian Maladaptif memiliki factor loadings yang lebih besar dari 0.00. Hal tersebut menandakan bahwa kelima faktor atau faktor (Antagonism, Detachment, Disinhibition, Negative Affectivity, \& Psychoticism) terbukti valid dalam mengukur konstruk Maladaptive Personality. Nilai Construct Reliability (CR) variabel Maladaptive Personality secara keseluruhan juga menunjukkan skor 0.917, CR > 0.7, yang menandakan tingkat reliabilitas yang baik. Secara umum, hasil CFA Second-Order untuk variabel Maladaptive Personality dapat dinyatakan good fit karena memiliki nilai RMSEA $=0.017$, RMSEA $<0.08, \chi 2($ Chi-Square $)=171.36, p>0.05$, dan GFI =0.98, GFI >0.9.

Tabel 2. Hasil pengujian konstruk Maladaptive Personality dengan indikator valid

\begin{tabular}{ccccccc}
\hline Konstruk & Faktor & $\begin{array}{c}\text { Factor } \\
\text { Loadings }\end{array}$ & t-value & $\begin{array}{c}\text { Standard } \\
\text { Error }\end{array}$ & Uji Faktor & $\mathbf{R}^{\mathbf{2}(\%)}$ \\
\hline $\begin{array}{c}\text { Maladaptive } \\
\text { Personality }\end{array}$ & Antagonism & 0.77 & 8.94 & 0.04 & Valid & 59 \\
\cline { 2 - 7 } $\begin{array}{c}\text {-value }=0.07433 \\
\chi^{2}=171.36\end{array}$ & Detachment & 0.95 & 12.76 & 0.04 & Valid & 91 \\
\cline { 2 - 7 } RMSEA $=0.017$ & Disinhibition & 0.64 & 11.00 & 0.04 & Valid & 41 \\
\cline { 2 - 7 } & $\begin{array}{c}\text { Negative } \\
\text { Affectivity }\end{array}$ & 0.91 & 14.34 & 0.04 & Valid & 82 \\
\cline { 2 - 7 } & Psychoticism & 0.86 & 10.43 & 0.04 & Valid & 74 \\
\hline
\end{tabular}

\section{HASIL DAN PEMBAHASAN}

\section{Gambaran data kepribadian maladaptif}

Secara empiris, skor Mean yang dimiliki oleh partisipan penelitian adalah 25.95 dengan nilai maksimum sebesar 62, dan nilai minimum sebesar 4, dan SD sebesar 8.70. Nilai tersebut lebih rendah daripada Mean hipotetik, yaitu 36. Dengan kata lain, secara umum partisipan penelitian memiliki tingkat disfungsi kepribadian yang cenderung rendah.

Berikut ini akan dijelaskan gambaran data kelima faktor Maladaptive Personality (Antagonism, Detachment, Disinhibition, Negative Affectivity, \& Psychoticism) pada partisipan penelitian. Adapun, profil kelima faktor tersebut didasarkan pada skor Mean tiap-tiap faktor Maladaptive Personality. Secara ringkas, gambaran data kelima faktor Maladaptive Personality yang ditemukan pada 608 partisipan dapat dilihat pada Tabel 3.

Tabel 3. Gambaran data faktor maladaptive personality $(n=608)$

\begin{tabular}{lcccc}
\hline Faktor & Mean Hipotetik & Mean Empirik & SD & Indeks*) (\%) \\
\hline Antagonism & 7.5 & 4.2319 & 2.20539 & 56.42 \\
\hline Detachment & 7.5 & 3.8207 & 2.51108 & 50.94 \\
\hline Disinhibition & 6 & 4.5115 & 2.22681 & 75.19 \\
\hline Negative Affectivity & 7.5 & 7.4589 & 2.88465 & 99.45 \\
\hline Psychoticism & 7.5 & 5.9424 & 2.80943 & 79.23 \\
\hline
\end{tabular}

*)Perbandingan nilai mean empirik relatif terhadap mean hipotetik 
Secara umum, faktor kepribadian maladaptif yang paling tinggi ada pada diri partisipan adalah Negative Affectivity. Hasil ini sejalan dengan penelitian sebelumnya (Granieri et al., 2017). Sedangkan, faktor yang paling rendah ada pada diri partisipan adalah Detachment. Dengan kata lain, jika dibandingkan dengan faktor-faktor Maladaptive Personality yang lain, partisipan penelitian memiliki kecenderungan mengalami pengalaman intensif dan sering akan berbagai perasaan negatif yang lebih besar. Sebaliknya, jika dibandingkan dengan faktor Maladaptive Personality yang lain, partisipan penelitian memiliki kecenderungan untuk menghindari pengalaman sosioemosional yang lebih kecil. Akan tetapi, berdasarkan data tersebut (Tabel 3) juga diketahui bahwa nilai Mean empirik pada kelima faktor lebih kecil daripada nilai Mean hipotetiknya. Hal tersebut mengindikasikan bahwa tingkat antagonism, detachment, disinhibition, negative affectivity, dan psychoticism yang dimiliki partisipan masih berada pada taraf cenderung rendah.

\section{Norma kategorisasi variabel penelitian}

Peneliti mengkategorisasikan data ke dalam tiga kelompok, yaitu Tinggi, Sedang, dan Rendah. Rincian mengenai kategorisasi tersebut dapat dilihat pada Tabel 4.

Tabel 4. Norma kategorisasi variabel kepribadian maladaptif

\begin{tabular}{lcc}
\hline Kategori & Rumus & Rentang Skor \\
\hline Tinggi & $\mathrm{X} \geq \mathrm{M}+1 \mathrm{SD}$ & $\mathrm{X} \geq 48$ \\
\hline Sedang & $\mathrm{M}-1 \mathrm{SD} \leq \mathrm{X}<\mathrm{M}+1 \mathrm{SD}$ & $24 \leq \mathrm{X}<48$ \\
\hline Rendah & $\mathrm{X}<\mathrm{M}-1 \mathrm{SD}$ & $\mathrm{X}<24$ \\
\hline
\end{tabular}

Berdasarkan kategorisasi data yang telah dilakukan pada variabel Maladaptive Personality, diperoleh hasil sebagai berikut. Partisipan yang tergolong dalam kategori Tinggi berjumlah 7 orang $(1.2 \%)$. Nilai tersebut juga dapat diartikan bahwa pada penelitian ini partisipan yang memiliki tingkat disfungsi kepribadian yang tinggi berjumlah 7 orang. Kemudian, partisipan yang tergolong dalam kategori Sedang berjumlah 365 orang $(60 \%)$. Hal tersebut juga berarti bahwa pada penelitian ini partisipan yang memiliki tingkat disfungsi kepribadian pada taraf sedang berjumlah 365 orang. Lalu, partisipan yang tergolong dalam kategori Rendah berjumlah 236 orang $(38.8 \%)$. Hal tersebut berarti pada penelitian ini partisipan yang memiliki tingkat disfungsi kepribadian yang rendah berjumlah 236 orang. Namun, hasil tersebut merupakan hasil yang didapatkan secara hipotetik atau teoretis karena didasarkan pada norma yang dirumuskan secara teoretis.

\section{Perbandingan profil faktor kepribadian maladaptif berdasarkan tingkat.disfungsi kepribadian}

Peneliti melakukan uji beda (Kruskal-Wallis H test) pada kelima faktor kepribadian pada tiga kategori kepribadian maladaptif dan ditemukan nilai Chi-Square sebesar 171.963 (Disinhibition), 226.206 (Psychoticism), 186.345 (Negative Affectivity), 214.984 (Detachment), dan 189.418 (Antagonism), $\mathrm{df}=2, \mathrm{p}<.05$, yang menandakan bahwa kelima faktor pada tiga kategori memiliki perbedaan peringkat mean yang signifikan. Perbedaan terbesar terletak pada faktor Psychoticism yang diikuti dengan Detachment antara golongan Tinggi dan Rendah. Dengan demikian, profiling mengenai 5 faktor kepribadian tersebut dapat dilakukan karena perbedaannya dapat dikatakan signifikan.

Adapun, profil dinamika kelima faktor tersebut didasarkan pada skor indeks (perbandingan Mean empirik terhadap Mean hipotetik) tiap-tiap faktor yang didapatkan dari jumlah partisipan pada tiap-tiap kategori tingkat disfungsi kepribadian. Hal tersebut dilakukan guna 
menstandarisasi perbandingan antarfaktor yang dimiliki partisipan pada tiap-tiap kelompok partisipan sehingga perbandingan antarfaktor dan antarkelompok dapat dilakukan secara simultan. Gambaran perbandingan profil kelima faktor Maladaptive Personality (Antagonism, Detachment, Disinhibition, Negative Affectivity, \& Psychoticism) pada tiap-tiap kategori tingkat disfungsi kepribadian dapat dilihat pada Gambar 1.

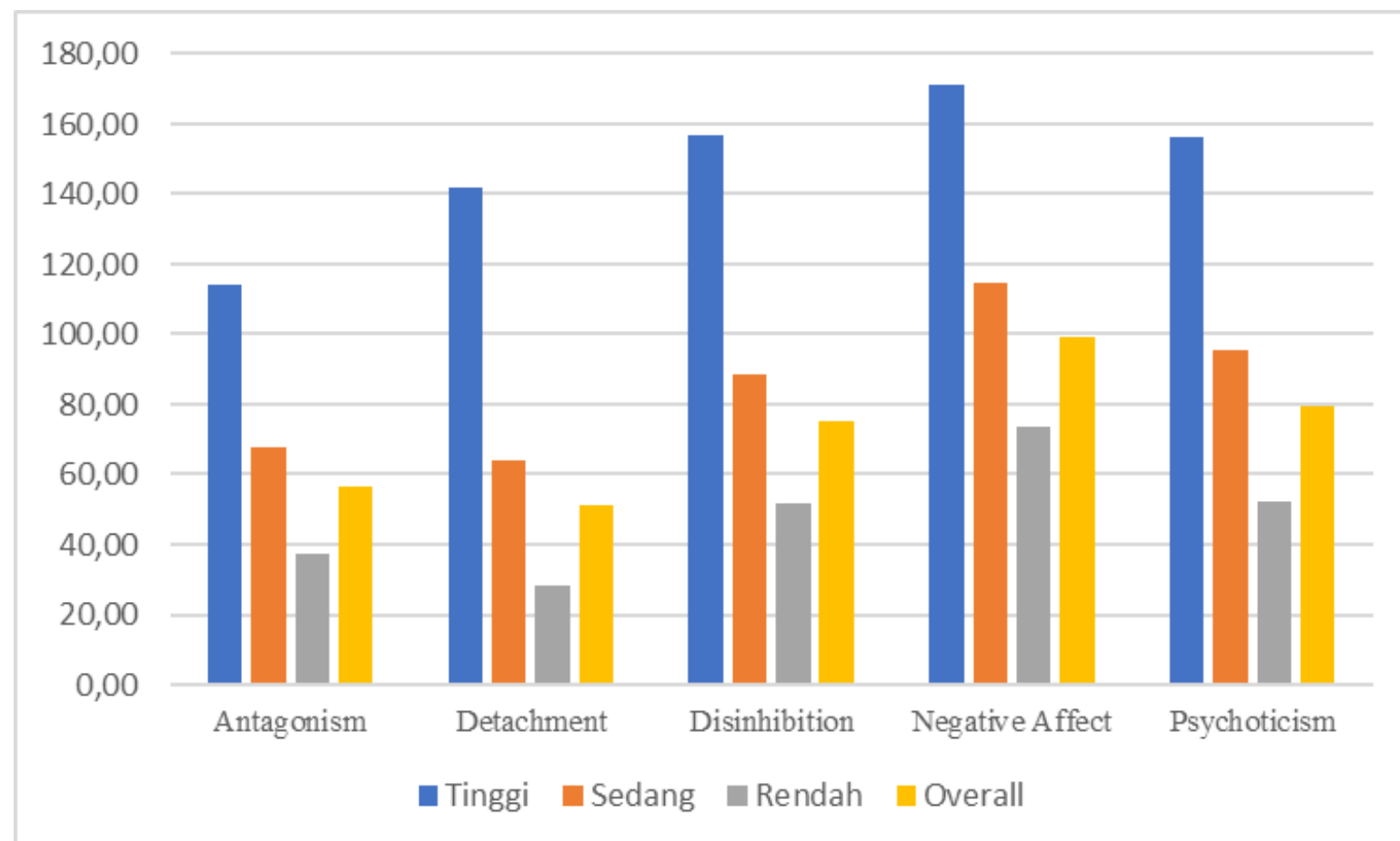

Gambar 1. Grafik perbandingan faktor kepribadian maladaptif berdasarkan tingkat disfungsi kepribadian

Pertama, diketahui bahwa jumlah partisipan yang terkategori pada kategori Tinggi berjumlah 7 orang. Berdasarkan analisis deskriptif kelima faktor Maladaptive Personality, didapatkan hasil seperti pada Tabel 5.

Tabel 5. Gambaran data faktor maladaptive personality pada partisipan dengan tingkat maladaptive personality tinggi $(n=7)$

\begin{tabular}{lcccc}
\hline Faktor & Mean Hipotetik & Mean Empirik & SD & Indeks*) (\%) \\
\hline Antagonism & 7.5 & 8.5714 & 2.20539 & 114 \\
\hline Detachment & 7.5 & 10.7143 & 2.51108 & 142 \\
\hline Disinhibition & 6 & 9.4286 & 2.22681 & 157 \\
\hline Negative Affectivity & 7.5 & 12.8571 & 2.88465 & 171.4 \\
\hline Psychoticism & 7.5 & 11.7143 & 2.80943 & 156 \\
\hline
\end{tabular}

*)Perbandingan nilai mean empirik relatif terhadap mean hipotetik

Berdasarkan data tersebut (Tabel 5) juga diketahui bahwa nilai Mean empirik pada kelima faktor lebih besar daripada nilai Mean hipotetiknya. Hal tersebut mengindikasikan bahwa tingkat antagonism, detachment, disinhibition, negative affectivity, dan psychoticism yang dimiliki partisipan di kategori Tinggi berada pada taraf tinggi.

Secara deskriptif, ciri utama partisipan yang tergolong dalam kategori ini adalah memiliki kecenderungan yang sangat tinggi untuk mengalami pengalaman intensif akan berbagai perasaan negatif yang intens, seperti sedih, cemas, takut, gelisah, dan marah yang berlebihan sehingga 
lebih rentan melakukan self-harm dan cenderung lebih dependen pada orang lain. Partisipan pada kategori ini cenderung berperilaku impulsif tanpa mempertimbangkan konsekuensi dalam rangka mendapatkan gratifikasi yang segera. Kemudian, partisipan juga memiliki kecenderungan yang tinggi untuk menunjukkan pola perilaku dan atau kognisi yang tidak wajar dan aneh. Perilaku yang eksentrik tersebut seringkali dianggap tidak wajar oleh masyarakat. Selanjutnya, partisipan juga memiliki kecenderungan yang tinggi untuk menarik diri dari pengalaman-pengalaman sosioemosional, seperti tidak tertarik untuk menjalin relasi dengan orang lain dan menutup diri pengalaman-pengalaman yang memunculkan reaksi afektif.

Partisipan pada kategori ini juga memiliki kecenderungan untuk menempatkan diri sebagai oposisi orang lain atau mementingkan dirinya secara berlebihan, tetapi jika dibandingkan dengan faktor lainnya, perilaku ini tidak dominan. Mengacu pada hasil uji beda, perbedaan paling besar yang terlihat pada perilaku partisipan yang terkategori Tinggi dan Rendah adalah kecenderungan untuk menarik diri dari pengalaman sosioemosional dan menunjukkan perilaku yang eksentrik atau dianggap aneh.

Kedua, diketahui bahwa jumlah partisipan yang tergolong dalam kategori Sedang berjumlah 365 orang. Berdasarkan analisis kelima faktor Maladaptive Personality, didapatkan hasil seperti pada Tabel 6.

Tabel 6. Gambaran data faktor maladaptive personality pada partisipan dengan tingkat maladaptive personality sedang $(n=365)$

\begin{tabular}{lcccc}
\hline Faktor & Mean Hipotetik & Mean Empirik & SD & Indeks*)(\%) \\
\hline Antagonism & 7.5 & 5.0757 & 2.03935 & 67.7 \\
\hline Detachment & 7.5 & 4.7973 & 2.25990 & 63.96 \\
\hline Disinhibition & 6 & 5.3260 & 1.97248 & 88.77 \\
\hline Negative Affectivity & 7.5 & 8.6000 & 2.45822 & 114.67 \\
\hline Psychoticism & 7.5 & 7.1397 & 2.36613 & 95.2 \\
\hline
\end{tabular}

*)Perbandingan nilai mean empirik relatif terhadap mean hipotetik

Berdasarkan data tersebut (Tabel 6) juga diketahui bahwa nilai Mean empirik pada keempat faktor, selain Negative Affectivity, lebih kecil daripada nilai Mean hipotetiknya. Hal tersebut mengindikasikan bahwa tingkat antagonism, detachment, disinhibition, dan psychoticism yang dimiliki partisipan berada pada taraf cenderung rendah. Namun, hampir sama halnya dengan partisipan pada kategori tinggi, partisipan dalam kategori ini memiliki tingkat Negative Affectivity yang cenderung tinggi.

Secara deskriptif, ciri utama partisipan yang tergolong dalam kategori ini adalah memiliki kecenderungan untuk lebih sering mengalami pengalaman intensif akan berbagai perasaan negatif yang intens, seperti sedih, cemas, takut, gelisah, dan marah yang berlebihan walaupun tidak seintensif partisipan pada kategori tinggi. Dengan kata lain, partisipan cukup sering menunjukkan emosi negatif, tetapi tidak berlebihan. Kemudian, partisipan juga memiliki kecenderungan untuk berperilaku dan atau berpikiran yang tidak wajar dan seringkali aneh, tetapi tidak separah partisipan yang tergolong dalam kategori tinggi (masih berada dalam batas kewajaran).

Selanjutnya, partisipan juga memiliki sedikit kecenderungan untuk berperilaku impulsif. Walaupun demikian, partisipan pada kategori ini masih dapat mendahulukan kepentingan orang lain di atas kepentingan dirinya dan memiliki keinginan untuk terlibat dalam pengalaman sosioemosional. Perbedaan paling besar yang terlihat pada perilaku partisipan yang terkategori Sedang dan Tinggi adalah kecenderungannya untuk menarik diri dari pengalaman 
sosioemosional dan kecenderungan untuk berperilaku impulsif. Dapat dikatakan juga bahwa partisipan yang terkategori Sedang cenderung lebih tidak menarik diri dan tidak impulsif dari partisipan yang terkategori Tinggi.

Terakhir, diketahui bahwa jumlah partisipan yang tergolong dalam kategori Rendah berjumlah 236 orang. Berdasarkan analisis kelima faktor Maladaptive Personality, didapatkan hasil seperti pada Tabel 7.

Tabel 7. Gambaran data faktor maladaptive personality pada partisipan dengan tingkat maladaptive personality rendah $(n=236)$

\begin{tabular}{lcccc}
\hline Faktor & Mean Hipotetik & Mean Empirik & SD & Indeks*) (\%) \\
\hline Antagonism & 7.5 & 2.7966 & 1.50211 & 37.28 \\
\hline Detachment & 7.5 & 2.1059 & 1.54693 & 28.08 \\
\hline Disinhibition & 6 & 3.1059 & 1.70400 & 51.76 \\
\hline Negative Affectivity & 7.5 & 5.5339 & 2.33997 & 73.78 \\
\hline Psychoticism & 7.5 & 3.9195 & 2.07874 & 52.26 \\
\hline
\end{tabular}

*)Perbandingan nilai mean empirik relatif terhadap mean hipotetik

Berdasarkan data tersebut (Tabel 7) diketahui bahwa nilai Mean empirik pada kelima faktor lebih kecil daripada nilai Mean hipotetiknya. Hal tersebut mengindikasikan bahwa tingkat antagonism, detachment, disinhibition, negative affectivity, dan psychoticism yang dimiliki partisipan di kategori Rendah berada pada taraf rendah.

Secara deskriptif, ciri utama partisipan yang tergolong dalam kategori ini adalah memiliki kecenderungan mengalami pengalaman intensif akan berbagai perasaan negatif, seperti sedih, cemas, takut, gelisah, dan marah yang tidak berlebihan sehingga cenderung lebih sedikit merasakan dan menunjukkan emosi negatif dibandingkan dengan partisipan pada kategori Sedang. Kemudian, partisipan juga hanya sedikit memiliki kecenderungan untuk berperilaku atau berpikiran yang tidak wajar sehingga perilakunya masih dapat dilihat sebagai perilaku yang dapat diterima dalam norma masyarakat. Selanjutnya, partisipan hanya sedikit memiliki kecenderungan untuk berperilaku impulsif. Lalu partisipan juga memiliki kecenderungan untuk bersikap antagonistik yang rendah sehingga perilaku yang ditunjukkan cenderung mengikuti norma yang berlaku atau bahkan bersifat prososial. Berdasarkan skor indeks mean faktor detachment yang paling rendah, partisipan yang terkategori Rendah hanya sedikit sekali memiliki kecenderungan untuk menarik diri dari pengalaman sosioemosional sehingga memiliki kecenderungan yang lebih besar untuk terlibat dalam kegiatan sosial dan tidak merasa terisolasi. Perbedaan paling besar yang membedakan karakteristik partisipan yang tergolong Sedang dan Rendah terletak pada kadar faktor negative affectivity dan psychoticism. Hal tersebut menandakan bahwa partisipan pada kategori rendah lebih sedikit merasakan dan menunjukkan emosi negatif dalam kesehariannya serta lebih banyak menunjukkan perilaku yang dapat diterima dalam masyarakat.

Secara umum, temuan-temuan dalam penelitian ini sejalan dengan studi lintas budaya yang dilakukan Keyes et al. (2020) yang menemukan bahwa terdapat tiga hal utama yang menjadi indikator kesehatan mental seseorang, yaitu emosi positif (happiness), mental yang stabil, dan keterhubungan secara sosial. Pada penelitian ini, ditemukan kadar negative affectivity yang tinggi pada partisipan berkategori Tinggi dan Sedang. Hal ini sekaligus mengindikasikan bahwa orangorang yang lebih berpotensi memiliki gangguan kepribadian cenderung lebih sedikit merasakan emosi positif dibandingkan dengan partisipan yang memiliki tingkat disfungsi kepribadian rendah. Selain itu, orang-orang dengan tingkat negative affectivity yang rendah akan cenderung 
merasakan ketenangan mental yang lebih banyak karena tidak rentan mengalami emosi negatif yang intens. Hal ini juga dapat mengindikasikan bahwa orang-orang dengan tingkat negative affectivity yang lebih rendah cenderung lebih stabil secara mental.

Kemudian, ditemukan juga perbedaan kadar faktor detachment dan psychoticism yang signifikan antara kelompok Tinggi dan Rendah. Hasil ini sekaligus mengindikasikan bahwa orang-orang yang memiliki tingkat disfungsi kepribadian tinggi lebih banyak menunjukkan perilaku dan pemikiran tidak wajar yang seringkali tidak sejalan dengan norma yang berlaku. Selain itu juga, pada orang-orang tersebut ditemukan kecenderungan untuk menarik diri dari lingkungan sosioemosional. Kedua hal itu yang kemudian memisahkan atau menjauhkan orang-orang tersebut dari lingkungan sosial sehingga cenderung merasa tidak terkoneksi secara sosial.

Meskipun begitu, penelitian ini tidak luput dari beberapa keterbatasan. Sampel pada penelitian ini masih terbatas pada golongan dan daerah tertentu sehingga hasil yang didapatkan belum tentu dapat digeneralisasikan pada sampel lainnya pada populasi yang sama atau populasi lainnya.

\section{KESIMPULAN DAN SARAN}

Sebagai simpulan, ditemukan prevalensi partisipan dengan disfungsi kepribadian bertaraf tinggi sebanyak 7 orang (1.2\%), sedang sebanyak 365 orang (60\%), dan disfungsi kepribadian bertaraf rendah sebanyak 236 orang $(38.8 \%)$. Adapun, pada tiap-tiap kategori partisipan ditemukan profil faktor kepribadian yang berbeda. Namun, secara umum, penelitian ini menemukan faktor negative affectivity adalah faktor yang paling besar dimiliki oleh partisipan pada tiap-tiap kategori. Kemudian, ditemukan juga kadar negative affectivity yang rendah pada partisipan dengan tingkat disfungsi kepribadian yang rendah. Terakhir, perbedaan karakteristik paling besar antara partisipan yang berada pada kategori Tinggi dan Rendah terletak pada faktor psychoticism dan detachment.

Walaupun alat ukur ini sudah dapat memberikan gambaran bahwa dapat dipergunakan pada sampel, masih diperlukan penelitian lebih lanjut dengan sampel yang lebih besar dengan kelompok usia yang lebih merata. Dalam penelitian ini, 89,1\% pasrtisipan adalah mahasiswa yg berusia 17-18 tahun, sementara itu fase dewasa awal berkisar antara $17-25$ tahun. Peneliti selanjutnya dapat menggunakan sampel yang lebih proporsional secara jumlah dan bersifat majemuk dengan tetap melakukan kontrol terhadap faktor-faktor yang berpotensi memengaruhi hasil. Hal tersebut dapat dilakukan guna mendapatkan gambaran hasil yang lebih ajeg dan dapat digeneralisasi pada populasi. Meskupun begitu, penelitian ini dapat bermanfaat sebagai masukan yang positif untuk para psikolog klinis, psikoterapis, dan masyarakat. Bagi para psikolog klinis dan psikoterapis, penelitian ini dapat digunakan untuk menjadi bahan pertimbangan dalam melakukan screening atau asesmen terhadap gangguan kepribadian pada dewasa awal. Bagi masyarakat, terkhususnya yang berada pada rentang usia dewasa awal dan mengalami permasalahan kepribadian, hasil penelitian ini dapat memberikan insight mengenai keadaan yang dialaminya sehingga dapat mencari bantuan pada ahli jika memang diperlukan.

\section{Ucapan Terima Kasih (Acknowledgement)}

Peneliti mengucapkan terima kasih pada Tuhan yang Maha Esa, Universitas Tarumanagara, dan juga kepada partisipan pada penelitian ini. 


\section{REFERENSI}

American Psychiatric Association (APA). (2013). Diagnostic and Statistical Manual of Mental Disorders (5th ed.). Washington, DC: American Psychiatric Association.

Anderson, J. L., Sellbom, M., \& Salekin, R. T. (2018). Utility of the Personality Inventory for DSM-5-Brief Form (PID-5-BF) in the measurement of maladaptive personality and psychopathology. Assessment, 25(5), 596-607. Diakses dari https://doi.org/10.1177/1073191116676889

Anna, L. K. (2012, Februari 11). Gangguan jiwa masih diabaikan. Diakses dari https://lifestyle.kompas.com/read/2012/02/11/07363466/Gangguan.Jiwa.Masih.Diabaika $\mathrm{n}$ ?page $=2$

Bach, B., Maples-Keller, J. L., Bo, S., \& Simonsen, E. (2016). The alternative DSM-5 personality disorder traits criterion: A comparative examination of three self-report forms in a Danish population. Personality Disorders: Theory, Research, and Treatment, 7(2), 124-135. Diakses dari https://doi.org/10.1037/per0000162

Bastiaens, T., Claes, L., Smits, D., De Clercq, B., De Fruyt, F., Rossi, G., ... \& De Hert, M. (2016). The construct validity of the Dutch Personality Inventory for DSM-5 Personality Disorders (PID-5) in a clinical sample. Assessment, 23(1), 42-51. Diakses dari https://doi.org/10.1177/1073191115575069

Fossati, A., Krueger, R. F., Markon, K. E., Borroni, S., Maffei, C., \& Somma, A. (2015). The DSM-5 alternative model of personality disorders from the perspective of adult attachment: a study in community-dwelling adults. The Journal of nervous and mental disease, 203(4), 252-258. Diakses dari doi: 10.1097/NMD.0000000000000274

Granieri, A., La Marca, L., Mannino, G., Giunta, S., Guglielmucci, F., \& Schimmenti, A. (2017). The relationship between defense patterns and DSM-5 maladaptive personality domains. Frontiers in psychology, 8, 1926. Diakses dari https://doi.org/10.3389/fpsyg.2017.01926

Kementerian Kesehatan Republik Indonesia (Kemenkes). (2013). Riset Kesehatan Dasar 2013. Jakarta: Kemenkes.

Keyes, C. L. M., Sohail, M. M., Molokwu, N. J., Parnell, H., Amanya, C., Kaza, V. G. K., ... Proeschold-Bell, R. J. (2020). How Would You Describe a Mentally Healthy Person? A Cross-Cultural Qualitative Study of Caregivers of Orphans and Separated Children. Journal of Happiness Studies. Diakses dari doi:10.1007/s10902-020-00293-X

Krueger, R. F., Derringer, J., Markon, K. E., Watson, D., \& Skodol, A. E. (2012). Initial construction of a maladaptive personality trait model and inventory for DSM-5. Psychol. Med. 42, 1879-1890. Diakses dari doi: 10.1017/S0033291711002674

Krueger, R. F., Eaton, N. R., Clark, L. E., Watson, D., Markon, K. E., Derringer, J., . . Livesley, W. J. (2011). Deriving an empirical structure of personality pathology for DSM-5. Journal of Personality Disorders, 25, 170-191. Diakses dari https://doi.org/10.1521/pedi.2011.25.2.170

Lenzenweger, M. F., Lane, M. C., Loranger, A. W., \& Kessler, R. C. (2007). DSM-IV personality disorders in the National Comorbidity Survey Replication. Biological psychiatry, 62(6), 553-564. Diakses dari https://doi.org/10.1016/j.biopsych.2006.09.019

Liebke, L., Bungert, M., Thome, J., Hauschild, S., Gescher, D. M., Schmahl, C., ... \& Lis, S. (2017). Loneliness, social networks, and social functioning in borderline personality disorder. Personality Disorders: Theory, Research, and Treatment, 8(4), 349. Diakses dari https://doi.org/10.1037/per0000208

Moran, P., Romaniuk, H., Coffey, C., Chanen, A., Degenhardt, L., Borschmann, R., \& Patton, G. C. (2016). The influence of personality disorder on the future mental health and social adjustment of young adults: a population-based, longitudinal cohort study. The Lancet Psychiatry, 3(7), 636-645. Diakses dari https://doi.org/10.1016/S2215-0366(16)30029-3 
Morey, L. C., Benson, K. T., \& Skodol, A. E. (2016). Relating DSM-5 section III personality traits to section II personality disorder diagnoses. Psychological Medicine, 46(3), 647655. Diakses dari doi:10.1017/S0033291715002226

Quirk, S. E., Berk, M., Chanen, A. M., Koivumaa-Honkanen, H., Brennan-Olsen, S. L., Pasco, J. A., \& Williams, L. J. (2016). Population prevalence of personality disorder and associations with physical health comorbidities and health care service utilization: A review. Personality Disorders: Theory, Research, and Treatment, 7(2), 136. Diakses dari https://doi.org/10.1037/per0000148

Reichborn-Kjennerud, T., Krueger, R. F., Ystrom, E., Torvik, F. A., Rosenström, T. H., Aggen, S. H., ... \& Czajkowski, N. O. (2017). Do DSM-5 Section II personality disorders and Section III personality trait domains reflect the same genetic and environmental risk factors?. Psychological medicine, 47(12), 2205-2215. Diakses dari doi:10.1017/S0033291717000824

Volkert, J., Gablonski, T. C., \& Rabung, S. (2018). Prevalence of personality disorders in the general adult population in Western countries: systematic review and meta-analysis. The British Journal of Psychiatry, 213(6), 709-715.

Wingenfeld, K., Duesenberg, M., Fleischer, J., Roepke, S., Dziobek, I., Otte, C., \& Wolf, O. T. (2018). Psychosocial stress differentially affects emotional empathy in women with borderline personality disorder and healthy controls. Acta Psychiatrica Scandinavica, 137(3), 206-215. Diakses dari https://doi.org/10.1111/acps. 12856 